\title{
Hodnocení implementace znalostního managementu
}

\author{
Petr Pergner ${ }^{1}$, Jan Horejc ${ }^{2}$ \\ ${ }_{1}$ Západočeská univerzita v Plzni, Fakulta strojní, Katedra průmyslového inženýrství a \\ managementu \\ Univerzitní 8, 306 14, Plzeň, Česká republika \\ petr.pergner@doosan.com \\ ${ }_{2}$ České vysoké učení technické v Praze, Fakulta strojní, Ústav řízení a ekonomiky podniku \\ Karlovo náměstí 13, 12135 , Praha, Česká republika \\ jan.horejc@fs.cvut.cz
}

\begin{abstract}
Anotace: V současné době dochází k rostoucímu počtu implementací nástrojů znalostního managementu. Současně se s každou takovouto implementací objevuje i otázka hodnocení efektivity této implementace. Článek předkládá návrh možného maturity modelu hodnocení této efektivity, náčrt metodiky jeho tvorby i ukázku jeho použití ve vybraném podniku.
\end{abstract}

\section{1 Úvod}

Práce se znalostmi se $v$ průběhu vývoje podniku mění a postupně dospívá. $Z$ literatury je známo několik modelů vývoje $Z M \vee v$ organizaci. Tyto modely se liší svými přístupy k řešení problému, avšak nenalezl jsem žádný model, který by byl vytvořený prímo pro průmyslový podnik (dále jen podnik). Proto byl $v$ rámci dizertační práce $v$ souladu $s$ úkoly definovanými $v$ kap. č. 2 vytvořen vlastní model maturity modelu ZM s tímto zaměřením a následně byl tento model otestován v podmínkách konkrétního vybraného podniku (viz kap. č. 11).

Navržený model zohledňuje celkem 5 etap na cestě k plně funkčnímu ZM v podniku. Bere pritom $v$ úvahu vývoj práce se znalostmi $v$ podniku od zcela spontánního vzniku, předávání a využívání znalostí až po stav, kdy je systematický ZM nedílnou součástí fungování podniku se zásadním a trvalým př́nosem pro jeho konkurenceschopnost, trvalé zlepšování všech interních procesů a budoucí směřování a investice. Úroveň dospělosti ZM je hodnocena ve všech hlavních oblastech fungování podniku. I když se podniky od sebe liší svým zaměřením, uvažuji u podniků zvolené velikosti a organizačního zařazení (SBU) hodnocení dospělosti ZM v následujících oblastech ( $v$ různých podnicích může být různý dưraz na jednotlivé oblasti):

1. Věda a výzkum

2. Výroba

3. Finance

4. Lidské zdroje

5. Marketing

6. Obchod 
Jelikož ZM je postaven na využití a integraci poznatků z exaktních i neexaktních věd, není jeho přímá algoritmizace a komplexní zpracování ICT aplikacemi možná. $Z$ tohoto důvodu byly pro určení úrovně ZM v konkrétním podniku z pohledu maturity modelu získány názory vybraných manažerů a specialistů formou odpovědí na vybrané otázky zaměřené na úroveň konkrétního faktoru $Z M v$ daném podniku. Práce se znalostmi $v$ podniku je rozdělena $v$ pojetí této dizertační práce do pěti úrovní z pohledu dospělosti ZM (maturity modelu ZM) - níže jsem uvedl jejich základní atributy:

- Nultá úroveň - ad hoc práce se znalostmi

- První úroveň - vzniká software na archivaci a snadné nalezení a zpřístupnění znalostí

- Druhá úroveň - vzniká software na analýzu problémů a predikci potřebných znalostí

- Třetí úroveň - vzniká sofistikovaný aparát na vyhodnocování nákladů ZM a vzniká znalostní strategie podniku

- Čtvrtá úroveň - znalostní strategie je integrována s podnikovou strategií a vzniká učící se organizace

Na základě vyhodnocení odpovědí manažerů a specialistů se hodnotí úroveň fungování ZM ve všech výše uvedených sedmi hlavních oblastech podniku. Konkrétní podnik ve svém vývoji nemusí nutně projít všemi fázemi vývoje ZM záleží samozřejmě na době vzniku, délce trvání existence podniku a jeho finančních, personálních, technických a jiných možnostech. Při zavádění ZM je vhodné využít služeb osvědčené konzultační firmy, která již má potřebné zkušenosti s jeho zaváděním v jiných podnicích.

\section{$2 \quad$ Návrh maturity modelu znalostního managmentu}

\subsection{Nultá úroveň}

Název nultá byl zvolen proto, že na této úrovni ZM není předpokládána žádná systematická práce se znalostmi v podniku - znalosti vznikají spontánně při každodenní práci řešením úkolů podniku v průběhu podnikových procesů a ukládají se v hlavách řešitelů problémů, týmech, dokumentech, výkresech či analýzách (ad hoc práce se znalostmi). Chybějící znalost se získá obvykle kontaktováním jednoho nebo několika odborníků (metoda pokus-omyl), při řešení konkrétního problému či samostudiem příslušného dokumentu (výkresu, analýzy, technické zprávy atd.). Nultá úroveň dospělosti ZM je dále charakterizována následujícími atributy:

- Není žádný aparát na ukládání a vyhledání potřebné znalosti

- Není žádný ucelený přehled o aktuálním stavu znalostí v podniku

- Není žádný aparát na vyhodnocování stavu existujících znalostí a definici těch chybějících

- Není žádný sofistikovaný plán na získání nových znalostí 


\subsection{První úroveň}

Na této úrovni ZM vznikají v ICT aplikacích podniku cíleně databáze a úložiště pro ukládání a řízenou archivaci explicitních znalostí ve formě výkresů, výpočtů, analýz či technických zpráv a potřebná infrastruktura a software pro jejich snadné nalezení a zpřístupnění. První úroveň dospělosti $Z M$ je dále charakterizována následujícími atributy:

- Vzniká základní klasifikace existujících znalostí (přiřazeny základní atributy definující význam, využitelnost dané znalosti a další potřebné atributy

- Vzniká aparát na vyhledávání existujících znalostí

- Vzniká aparát na vyhodnocování stavu existujících znalostí

\subsection{Druhá úroveň}

Na této úrovni ZM vzniká v ICT aplikacích software na analýzu problémů signalizující, jaké znalosti v podniku jsou na nedostatečné úrovni a predikující, jaké nové znalosti budou potřeba v budoucnu pro jeho udržitelný rozvoj (propojení systémů marketingu a vývoje). Druhá úroveň dospělosti ZM je dále charakterizována následujícími atributy:

- Identifikují se znalostní zdroje a znalostní procesy

- Práce se znalostmi (resp. se znalostními úložišti) se automatizuje

- Precizuje se aparát na vyhodnocování stavu existujících znalostí a definici nutného dalšího rozvoje existujících znalostí

\subsection{Třetí úroveň}

Na této úrovni dochází k integraci znalostních a podnikových procesů a vzniká sofistikovaný procesní model a aparát na průběžné vyhodnocování úrovně ZM. Informační a znalostní systém se stává každodenním pomocníkem při práci (zaměstnanci nejsou zahlceni znalostmi, které nepotřebují, ale snadno vyhledají potřebné znalosti či kontakt na jejich majitele). Třetí úroveň dospělosti ZM je dále charakterizována následujícími atributy:

- Vzniká aparát na sledování nákladů na znalosti a znalostní procesy (vznik, ověřování, sdílení, používání, získání z externího prostředí podniku)

- Vznikaji sofistikované postupy, jak získat či zlepšit konkrétní znalosti včetně predikce nároků na zdroje a automatického sledování tohoto postupu

- Podnik zavádí systém pro rrízenou institucionalizaci aktuální platné explicitní znalosti

- Vzniká znalostní strategie jako nástroj k využití znalostního potenciálu podniku pro jeho přežití a další rozvoj (včetně metrik a indikátorů pro její plnění a vyhodnocování) podporující podnikovou strategii

Pro motivaci zaměstnanců $\mathrm{k}$ nepřetržitým inovacím v každodenní práci a sdílení znalostí je doposud nutný tlak vedení podniku. 


\section{5 Čtvrtá úroveň}

$\mathrm{Na}$ této úrovni se podnik získává základní znaky učící se organizace (nepřetržité zlepšování své práce $z$ pohledu inovací a úspěšnosti zákazníka $v$ jeho podnikání je $v$ hlavách zaměstnanců a nemusí být vynucováno vedením podniku). Propojují se metriky vyhodnocování znalostní a podnikové strategie a znalostní strategie se stává základním podpůrným dokumentem podnikové strategie. Čtvrtá úroveň dospělosti ZM je charakterizována nepřetržitým zlepšováním klíčových i podpůrných podnikových procesů postavených na znalostech směřujících $\mathrm{k}$ nepřetržitému růstu konkurenční výhody a dále pak následujícími atributy:

- Informační a znalostní systém získává komplexní sofistikovanou podobu umožňující pravidelnou validaci znalostní báze podniku na cestě $\mathrm{k}$ plánovanému stavu (s tím, jak se plní znalostní strategie podniku) včetně sledování nákladů a řízení rizik

- Uplatňují se prvky umělé inteligence - systémy pro manažerské rozhodování, systémy pro dolování v datech a extrakci znalostí, systémy pro predikci vývoje technologií či expertní systémy

- Podnik systematicky institucionalizuje aktuální platné explicitní znalosti při aktualizaci dané znalosti se řizeně reviduji všechny dokumenty, které jsou danou znalostí ovlivněny (takže jen aktuální verze jsou $k$ dispozici) a potřební pracovníci jsou o změně informováni prostřednictvím intranetu. Při inovacích výrobků i služeb je tak inovátorům k dispozici nejaktuálnější stav dané znalosti.

Nedílnou součástí vývoje ZM v podniku je i odpovídající adaptace organizační struktury podniku a podnikových procesů (klíčových i podpůrných) na aktuální vývoj podnikové strategie a s ní svázané znalostní strategie. Na obrázku 1 je komplexní blokový diagram vývoje maturity modelu v podniku. 

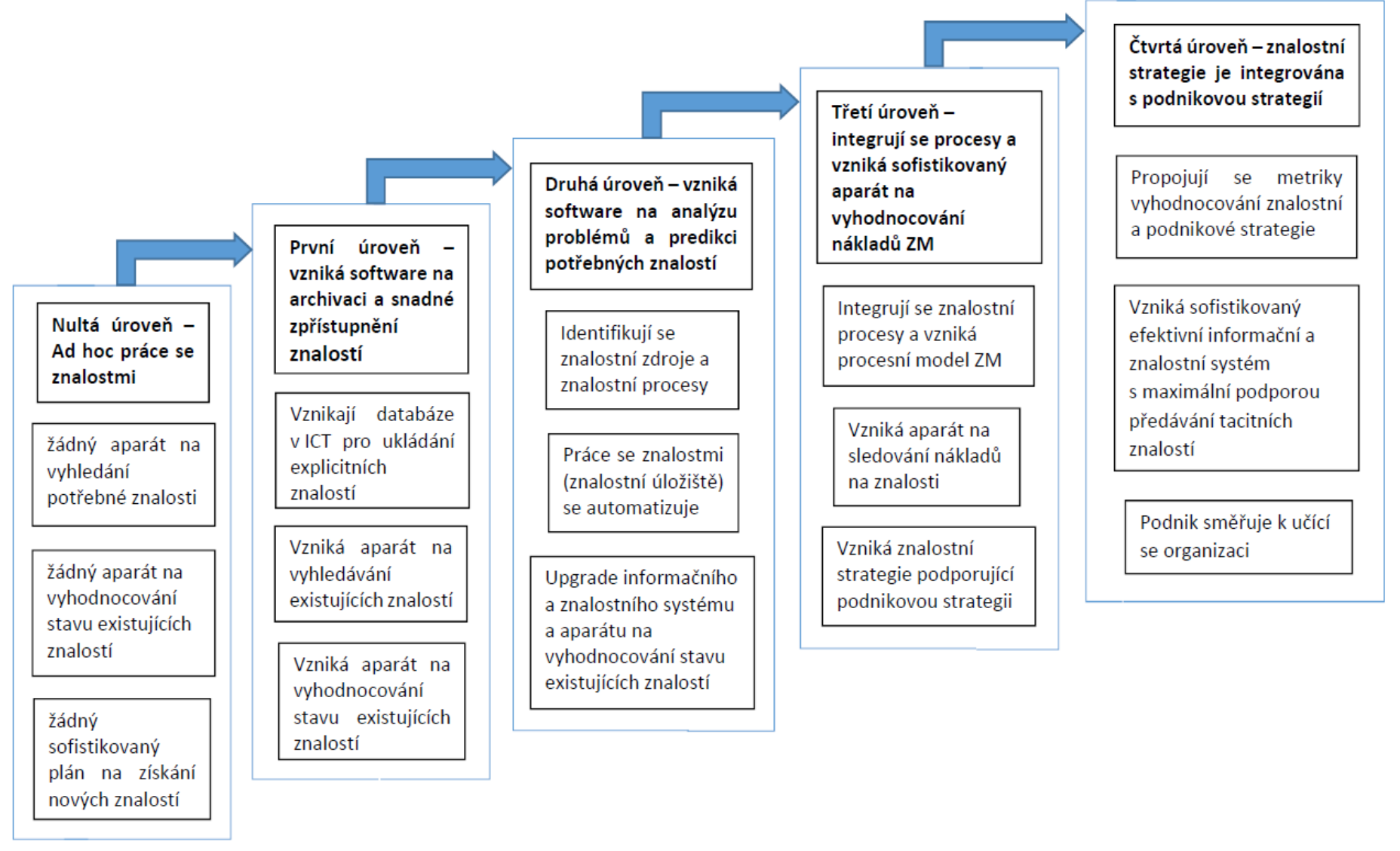

Obr. 1 - Maturity model znalostního managementu (vlastní)

\section{Hodnocení nasazení navržené metodiky}

Komplexní ověření navržené metodiky v konkrétním podniku bude vyžadovat delší časový horizont, nicméně již $v$ průběhu tvorby této dizertační práce je možno vyhodnotit některé dílčí kroky - konkrétně plnění metrik znalostní strategie za první rok její platnosti a dále pak vyhodnocení jednotlivých atributů stavu znalostí v podniku (informační a znalostní infrastruktury a ICT aplikací, znalostních zdrojů, znalostních procesů, firemních procesů a firemní kultury). Hodnocení probíhalo pomocí specializovaných dotazníků pro jednotlivé níže uvedené oblasti a podíleli se na něm jednak odborníci v dané oblasti, jednak vrcholoví podnikoví manažeři. Konkrétní finální hodnota pro jednotlivé výše uvedené atributy stavu znalostí v podniku vznikla zprůměrováním hodnocení jednotlivých dimenzí těchto atributů vybranými manažery a specialisty.

Základními oblastmi prováděných analýzy byly:

\section{- Analýza znalostní a informační infrastruktury}

Hodnoceny jsou zejména parametry uspořádání a fungování vytvořeného systému znalostního managementu v podniku. 


\section{- Analýza znalostních zdrojů}

Předmětem hodnocení byla kvalita a spolehlivost znalostních zdrojů v podniku, snadnost a efektivnost jejich využívání i bezpečnost, vy tvořená pro jejich zabezpečení. Pro ukázku ještě uved’me oblasti (zdroje), jichž se tato analýza týkala (viz tab. č. 1)

Tab. 1 - Maturity model znalostního managementu (vlastní)

\begin{tabular}{|l|l|}
\hline Znalostní oblast (zdroj) & Úroveň kodifikace a rozšíření \\
\hline $\begin{array}{l}\text { Hlavní část dodávaného } \\
\text { produktu }\end{array}$ & $\begin{array}{l}\text { dostatečná kodifikace, } \\
\text { nedostatečné rozšíření }\end{array}$ \\
\hline $\begin{array}{l}\text { Uvádění do provozu } \\
\text { dodávaného produktu }\end{array}$ & $\begin{array}{l}\text { dostatečná kodifikace, } \\
\text { nedostatečné rozšíření }\end{array}$ \\
\hline Provoz a jeho parametry & $\begin{array}{l}\text { nedostatečná kodifikace i } \\
\text { rozšírení }\end{array}$ \\
\hline $\begin{array}{l}\text { Servis, popř. opravy } \\
\text { dodávaného produktu }\end{array}$ & $\begin{array}{l}\text { nedostatečná kodifikace, } \\
\text { dostatečné rozšíření }\end{array}$ \\
\hline $\begin{array}{l}\text { Znalost klíčových zákazníků } \\
\text { v tradičních i nových } \\
\text { segmentech trhu }\end{array}$ & $\begin{array}{l}\text { nedostatečná kodifikace, } \\
\text { dostatečné rožíření }\end{array}$ \\
\hline
\end{tabular}

\section{- Analýza znalostních procesů podniku}

Třetí část analýza byla zaměřena na propracovanost a efektivitu nastavených znalostních procesư a podniku i jejich vzájemnou podmíněnost a provázanost.

\section{- Analýza klíčových firemních procesů}

Zároveň však bylo nutné podrobit analýze i ostatní podstatné procesy $v$ podniku, a to jak z hlediska jejich potřebnosti a efektivity, tak i z hlediska jejich podílu na celkové výkonnosti podniku.

\section{- Analýza firemní kultury z pohledu znalostí}

Tato analýza je nesmírně důležitá a vlastně testuje komplexně podmínky, které jsou v podniku vytvořeny jak pro jeho současné fungování, tak zejména pro možnost jeho dalšího rozvoje $v$ budoucnosti.

\section{- Sumarizace stavu znalostí}

Je závěrečnou částí prováděných analýz a kromě celkového matematického vyhodnocení úrovně podniku zhlediska fungování jeho (sub)systému znalostního managementu má dát i základní časové i obsahové impulsy $\mathrm{k}$ dalšímu rozvoji tohoto subsystému řízení podniku, a to i ve vazbě na další podstatné subsystémy systému řízení podniku, jako např. řízení inovací, 
technického a obchodního rozvoje, ale zejména ve vazbě na subsystém strategického managementu podniku.

Na uvedené analýzy a hodnocení pak přirozeně navazují aktivity, plány a programy definované ve znalostní strategii s využitím navržených metrik a indikátorů jejího plnění. Postupný růst znalostní báze podniku bude probíhat současně s plněním podnikové strategie, resp. funkčních podnikových strategií. Integrace plnění podnikové a znalostní strategie je zajištěna sladěním indikátorů a metrik plnění obou těchto strategií. Sledování plnění navržené metodiky bude kontinuální po dobu pěti let. Poté bude možno komplexně vyhodnotit její úspěšnost.

\section{Hodnocení vybraného podniku z hlediska maturity modelu}

\subsection{Hodnocení úrovně znalostního managementu v podniku}

Ve vybraném podniku bylo dalším dílčím cílem prověřit aktuální úroveň ZM $z$ pohledu maturity modelu teoreticky definovaného $v$ kap. 1 . Bylo stanoveno 7 klíčových oblasti chodu daného podniku a pro každou z těchto oblastí bylo nadefinováno 10 cílených otázek zaměřených na úroveň konkrétního faktoru ZM v podniku a o odpovědi byli požádáni vybraní manažeři a specialisté. Počet manažerů a specialistů byl zvolen tak, aby na každou z výše uvedených oblastí pripadal 1 manažer a 1 specialista. Celkem tak bylo tímto způsobem získáno 140 odpovědí (pro větší podnik je možno samožrejmě oslovit větší počet manažerů a specialistů). Pro hodnocení odpovědí byla sestavena pětistupňová škála $(0-4)$, kde $s$ rostoucím číslem roste kvalita zkoumaného faktoru ZM $v$ dané otázce - viz tab. č. 2.

Tab. 2 - Úrovně hodnocení daného faktoru ZM v podniku (vlastní)

\begin{tabular}{|l|l|}
\hline Hodnocení & Hodnocení faktoru ZM z pohledu maturity modelu \\
\hline 0 & nefungující \\
\hline 1 & nedokonale fungující bez konkrétního plánu na zlepšení \\
\hline 2 & nedokonale fungující s konkrétním plánem na zlepšení \\
\hline 3 & $\begin{array}{l}\text { nedokonale fungující s již částečně realizovaným konkrétním } \\
\text { plánem na zlepšení }\end{array}$ \\
\hline 4 & dokonale fungující \\
\hline
\end{tabular}

Výsledná hodnota jednotlivých faktorů ZM vznikla zprůměrováním odpovědí vybraných manažerů a specialistů.

Pro konkrétní finální zhodnocení aktuální úrovně ZM ve zkoumaných oblastech fungování podniku bylo použito následující rozčlenění - viz tab. č. 3. 
Tabr. 3 - Úrovně komplexního hodnocení ZM v podniku (vlastní).

\begin{tabular}{|l|l|}
\hline Výsledný index & $\begin{array}{l}\text { Komplexní hodnocení ZM z pohledu maturity } \\
\text { modelu }\end{array}$ \\
\hline $0-1.00$ & Nultá úroveň ZM \\
\hline $1.01-2$ & První úroveň ZM \\
\hline $2.01-3$ & Druhá úroveň ZM \\
\hline $3.01-4$ & Třetí úroveň ZM \\
\hline $4.01-5$ & Čtvrtá úroveň ZM \\
\hline
\end{tabular}

\subsection{Rozbor získaných odpovědí}

$Z$ dílčích odpovědí byla následně sestavena souhrnná tabulka úrovně ZM podniku v jeho jednotlivých oblastech (viz tab. č. 4) a následující radarový diagram (obr. č. 2) jako průměrné hodnocení vybraného speciality a manažera z vybrané oblasti podniku v deseti položených otázkách.

Tab. 4 - Úroveň ZM z pohledu maturity modelu ve vybraném podniku (vlastní).

\begin{tabular}{|l|c|c|}
\hline Zkoumaná oblast & $\begin{array}{c}\text { Výsledný } \\
\text { index } \\
\text { úrovně } \\
\text { ZM }\end{array}$ & $\begin{array}{c}\text { Komplexní hodnocení dané oblasti } \\
\text { podniku z pohledu maturity modelu ZM }\end{array}$ \\
\hline 1. Věda a výzkum & 2.30 & Druhá úroveň ZN \\
\hline 2. Výroba & 2.45 & Druhá úroveň ZN \\
\hline 3. Finance & 1.85 & První úroveň ZM \\
\hline 4. Lidské zdroje & 2.55 & Druhá úroveň ZN \\
\hline 5. Marketing & 1.45 & První úroveň ZM \\
\hline 6. Obchod & 1.80 & První úroveň ZM \\
\hline $\begin{array}{l}\text { Prưměrné } \\
\text { hodnocení } \\
\text { zkoumaných oblastí }\end{array}$ & 2.06 & Druhá úroveň ZM \\
\hline
\end{tabular}

Získané výsledky Ize pak zobrazit jak $v$ detailech (tj. daných zkoumaných oblastech), tak $\mathrm{i} v$ podobě celkového hodnocení implementace systému znalostního managementu podniku, které může mít např. tuto podobu (obrázek č. 2): 


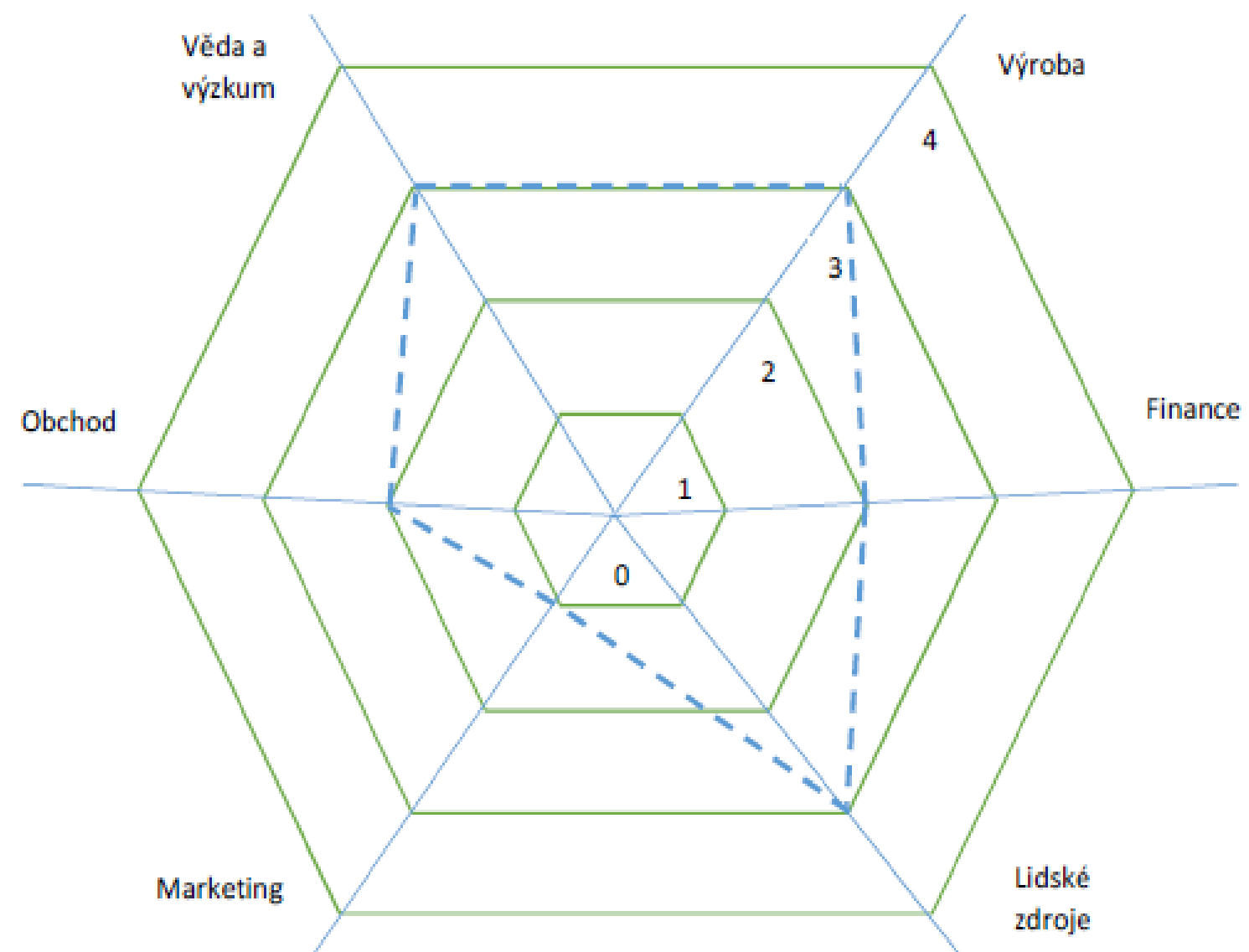

Obr. 2 - Přístup k řešení rizika z pohledu času a informací na vstupu (vlastní).

Ani jeden z manažerů a specialistů neohodnotil žádný faktor ZM stupněm 0 a stupněm 4. Nejlépe je hodnoceno fungování ZM $\vee$ oblastech lidských zdrojů, výroby a vědy a výzkumu, kde vyšla druhá úroveň ZM z pohledu maturity modelu. Hưre jsou pak s odkazem na stejnou tabulku hodnoceny oblasti financí a obchodu, kde vyšla první úroveň ZM z pohledu maturity modelu. Nejhưře byla hodnocena oblast marketingu, i když i zde vyšla finálně první úroveň ZM z pohledu maturity modelu. To ukazuje na nedostatečně rozvinuté vztahy s důležitými zákazníky a nedostatečné znalosti o jejich problémech a budoucích záměrech (to platí především pro nové zákazníky $v$ nových segmentech trhu, kde nebyl doposud dostatečný čas tyto vztahy a důvěru $\mathrm{k}$ podniku dostatečně vytvořit). Celkové průměrné hodnocení stavu ZM $\checkmark$ podniku spadá tedy do úrovně 2 zvoleného maturity modelu.

\section{Závěr}

Článek přináší návrh i metodiku vytvoření možného znalostního modelu podniku i jeho otestování v podmínkách vybraného podniku. Je nejen ukázkou určitého typu prístupu $\mathrm{k}$ řešení problémů znalostního managementu, ale současně jeho realizace ukázala i možné směry a úkoly jeho dalšího rozvoje, které budou publikovány po jejich dotvoření i opětovném otestování v podmínkách jiných vybraných podniků. 


\section{Poděkování}

Příspěvek byl vytvořen za podpory projektu SGS-2021-028 s názvem "Vývojové a tréninkové prostředky pro interakci člověka a kyber-fyzického výrobního systému“ řešeného $v$ rámci Interní grantové agentury Západočeské univerzity v Plzni.

\section{Použitá literatura}

[1] PERGNER, P. Znalostní management a jeho využití v průmyslových podnicích - Znalostní podpora tvorby podnikové strategie a dílčích strategií. Připravovaná Disertační práce ZČU v PIzni

[2] BUREŠ, V. Znalostní management a proces jeho zavádění. Průvodce pro praxi. Praha: Grada Publishing, 2007, 232 s. ISSN 978-80-247-1978-0.

[3] EL SAYED, A. Knowledge management and business strategies. Theoretical Frameworks and Empirical Research. IGI Global, 2008. 428 s., ISBN 9781599044866.

[4] MEIER, R. Implementing proces-oriented knowledge management strategies. Journal of knowledge management, 7(4), 2003., s. 62-74. ISSN 1367-3270.

[5] PAVELKOVÁ, D., KNÁPKOVÁ, A. FRIEDEL. L.: Využití moderních konceptů řízení výkonnosti pro měření vlivu vyspělých výrobních technologií na výkonnost podniku. Zlín: Trendy ekonomiky a managementu, 12/2012, Dostupné z: htttps://dspace.vutbr.cz/xmlui/handle/11012/20028.

[6] RAZAVI, K. The Relationship between Knowledge Management and Competitive Advantage. European Online Journal of Natural and Social Sciences, 2015, Vol. 4. ISSN 1805-3602. Dostupné z: http.//europeanscience.com/eojnss proc/article/download/4268/1990. 